Journal of Homosexuality

\title{
Portuguese Adolescents' Attitudes Toward Sexual Minorities: Transphobia, Homophobia, and Gender Role Beliefs
}

\section{Pedro Alexandre Costa PhD \& Michelle Davies PhD}

To cite this article: Pedro Alexandre Costa PhD \& Michelle Davies PhD (2012) Portuguese Adolescents' Attitudes Toward Sexual Minorities: Transphobia, Homophobia, and Gender Role Beliefs, Journal of Homosexuality, 59:10, 1424-1442, DOI: 10.1080/00918369.2012.724944

To link to this article: https://doi.org/10.1080/00918369.2012.724944

曲 Published online: 15 Nov 2012.

Submit your article to this journal ¿

III Article views: 1376

Q View related articles ¿

Citing articles: 46 View citing articles $\asymp$ 


\title{
Portuguese Adolescents' Attitudes Toward Sexual Minorities: Transphobia, Homophobia, and Gender Role Beliefs
}

\author{
PEDRO ALEXANDRE COSTA, PhD Candidate \\ Unidade de Investigação em Psicologia e Saúde, Instituto Superior \\ de Psicologia Aplicada, Lisboa, Portugal \\ MICHELLE DAVIES, PhD \\ School of Psychology, University of Central Lancashire, Preston, Lancashire, UK
}

Research has shown that negative attitudes toward lesbians and gay men are common and widespread in Western societies. However, few studies have addressed attitudes toward transgender individuals. In addition, although research has shown that homophobic harassment and bullying is highly common among adolescents, little is known about adolescent's attitudes toward sexual minorities. This study aimed to fill these gaps in knowledge, by investigating adolescents' attitudes toward transgender individuals and possible attitudinal correlates of those attitudes. Participants ( $\mathrm{N}=188$; 62 males and 126 females) were recruited in high schools in Lisbon, Portugal. Age ranged from 15 to 19 years ( $\mathrm{M}=$ 17 ; $\mathrm{SD}=.96)$. Participants completed a questionnaire booklet measuring attitudes toward transgender individuals, lesbians, and gay men, and gender role beliefs. Results revealed that attitudes toward transgender individuals were significantly correlated with all attitude measures. Specifically, it was revealed that those participants who endorsed negative attitudes toward transgender individuals were also endorsing of negative attitudes toward lesbians and gay men and tended to adhere to traditional gender roles. A significant gender effect was found with males being more negative toward sexual minorities than females, but these negative attitudes were more extreme toward gay men than toward lesbian women. Implications of these findings are discussed.

Address correspondence to Michelle Davies, School of Psychology, University of Central Lancashire, Preston, Lancashire PR1 2HE, UK. E-mail: mdavies3@uclan.ac.uk 
KEYWORDS attitudes, homophobia, transphobia, gender roles, adolescent development

\section{INTRODUCTION}

Discrimination and prejudicial attitudes are common topics in psychological research. Sexism and homophobia in particular have received considerable attention (Herek, 1988; Whitley, 2001) but only few studies have investigated attitudes toward transgender individuals. Transgenderism covers a wide spectrum of people who do not conform to prescribed gender roles and behaviors. It includes people who behave in ways perceived as legitimate of the opposite sex, who cross-dress, or people who undergo sex reassignment surgery (Bullough, 2006).

It is widely accepted that traditional societal values have restricted individuals' gender expressions and behaviors, thus, affecting the way gender nonconformist individuals form their sense of identity, including how gender identity, sexual identity, and sexual preferences are formed in adolescence. Rich (1983) called this the societal imposition of compulsory heterosexuality. The notion of compulsory heterosexuality is also closely linked with beliefs and expectations about gender roles. Individuals are socialized differently based on a division of sexes that are assigned at birth. Moreover, socially accepted sexual scripts determine desired gender behaviors in sexual and romantic relationships (Simon \& Gagnon, 1986). Rich (1983) proposed that compulsory heterosexuality is explicitly gendered, responsible for determining how individuals are supposed to behave (being more feminine or more masculine) and to which class of individuals (males or females) they should be attracted to.

There is some evidence that homophobia directed at gay men (Davies, 2000) and the endorsement of traditional gender role beliefs (Hill \& Willoughby, 2005) are closely linked with attitudes toward transgenderism. Hill and Willoughby (2005) suggested that the concept of transphobia, which "involves the feeling of repulsion [emotional disgust] toward masculine women, feminine men, cross-dressers, transgender individuals, and/or transsexuals" (p. 533) is multifaceted, focused around the negative endorsement of genderism.

Genderism is a concept similar to heterosexism (Hill \& Willoughby, 2005), adopted via society and institutional norms that reinforces the adoption of sex-typed behaviors and punishes individuals with gender nonconformity. In that sense, not only transgender persons are at risk of being victims of genderism, but also people who show any form of gender nonconformity. It is noteworthy that although negative attitudes toward transgender individuals and homophobia may be highly related dimensions, attitudes toward transgender individuals would not only be 
based on judgments on sexual orientation, but also on gender identity (Hill, 2002).

Attitudes toward lesbians and gay men are also complex and multifaceted (Davies, 2004; Kite \& Whitley, 1996, 1998). In their meta-analysis, Kite and Whitley (1996) identified three main categories of homophobia. The first category was related to a fear of lesbians and gay men and the management of homosexuality by means of social restrictions. The second category was related to the perception of homosexual acts as deviants and morally unacceptable. Finally, the third category was related to lesbian and gay men's civil rights. Further research by Davies (2004) has revealed that the first two categories of Kite and Whitley's categories combine to form one affective component, and attitudes toward the civil rights of lesbians and gay men, a different, cognitive component (see Davies, 2004, for further discussion). Moreover, Kite and Whitley (1996) and Davies (2004), among others, have shown that the relationship between homophobia and gender of the individual is influenced by their gender role beliefs.

Negative attitudes toward women's gender roles and attitudes toward traditional men's gender roles have been conceptualized as part of a patriarchal stratification of society, with penalties for those who cross-pass this gender barriers are worst for men than for women (Eagly, Wood, \& Johannesen-Schmidt, 2004). In that sense, although both men and women have their own gender scripts, male roles are constructed in opposition to femininity dimensions such as being romantically or sexually attracted to other males (Badinter, 1997). Men are socialized to endorse more rigid and restrictive gender roles than women, and part of the male gender socialization is to be homophobic and anti-feminine (Archer, 1984; Thompson, Grisanti, \& Pleck, 1985). It is then logical that males will be more defensive against those who cross-pass these gender barriers and, thus, are more homophobic.

Although the relationship between attitudes toward homosexuality and gender roles beliefs in adults is well established, little is known about the prevalence and value of these attitudes in adolescent development. Adolescence is a period of sexual identity construction and confirmation but it is not only constructed in concordance with one's own feelings and needs, but also in face of conflicting social influences (Erikson, 1968). Adolescents are faced with the hard task of responding to the society's demands that sometimes conflict with their own identity tasks. As adolescents go through different developmental stages, sexual identity becomes deeper and more solid and they gradually identify their specific needs, values, partner and activities' preferences, and models of sexual expression (Graber \& Archibald, 2001).

Whereas for young men, being masculine and heterosexual plays a major role in their development (Korobov, 2004; Plummer, 2001; Sharpe, 2002), young women are generally under less pressure to adjust to the prescribed gender roles, but, instead, are more likely to be pressured to 
grow up fast and to adjust to adult, caregiving roles. For that reason they might achieve a solid identity before their male counterparts (Adams, Ryan, Hoffman, Dobson, \& Nielsen, 1985). Moreover, among adolescents, homophobic bullying and name calling is very common. Often disregarded and unpunished by authority figures, these behaviors pave the way for the creation of an unsafe atmosphere for gender nonconformist adolescents. This atmosphere, thus, fosters negative attitudes and aggressive behaviors toward lesbians and gay men throughout their adolescence and adulthood (Korobov, 2004; Plummer, 2001).

Research has shown that the effects of homophobic harassment and bullying based on the perception of gender nonconformism can result in mental health problems, violent behavior, alcoholism, and substance abuse (Elze, 2003; Meyer, 2003). In a survey conducted by D'Augelli (1989), as many as 50\% of self-identified homosexual college students in their sample were victims of disparaging comments, and 36\% were threatened with physical assault, based on the perception of their gender nonconformist behaviors. Other studies showed that these acts of aggression have so pervasive effects that as many as 40\% of young lesbians and gay men had attempted suicide (Adam, Cox, \& Dunstan, 2004). Furthermore, sexual minority individuals are at higher risk than the norm of becoming victims of hate crime (Herek, 1989). Such victimization experiences are common among adolescents and can be more brutal and psychologically impairing than other types of crime (Rayburn \& Davidson, 2002, Willis, 2004).

In contrast, research has shown that knowing gender nonconformist individuals can actually change people's perceptions and attitudes toward them (Allport, 2000). Educating heterosexuals about lesbians and gay men's identities and having regular contact with them can reduce homophobic attitudes and behaviors. It is likely that having contact with transgender individuals may have a similar outcome (Lance, 2002a; Hill \& Willoughby, 2005).

The aim of the present study was to conduct an exploratory investigation of adolescents' attitudes toward transgender individuals and to explore possible attitudinal correlates of these attitudes such as affective reactions toward lesbians and gay men and adherence to traditional gender roles. As negative attitudes toward gender nonconformists and sexual minority individuals are quite common among mid- to late-adolescents, the current study utilized a sample who were aged between 15 and 19 years old. This study also extends previous research on the correlates of transphobia, which is currently lacking.

Most studies on attitudes toward sexual minorities have been conducted either in the United States or in the United Kingdom, and there is a lack of empirical research in this area in other Western countries. Little is known about the prevalence of negative attitudes toward sexual minorities in Portuguese adolescents; all that is currently published is based on anecdotal complaints from adolescent victims of homophobic bullying and discrimination (Rede ex aequo, 2006; 2008), with no current empirical work 
in support. The prevalence of bullying and harassment between peers in Portuguese schools are estimated in between 10 to 20\% of Portuguese children have experienced some form of bullying (Freire, 2001; Pereira \& Mendonça, 1995; Pereira, Almeida, Valente, \& Mendonça, 1996, Veiga Simão, Freire, \& Ferreira, 2004). Although no published research has explored homophobic bullying in particular in Portuguese adolescents, it is known that homophobic crimes are committed against sexual minorities in Portugal, such as a brutal attack and murder of a transsexual male in the north region of Portugal perpetrated by a group of young men (Organization for Security and Co-operation in Europe [OSCE], 2007). Further, a study published by the International Lesbian and Gay Association (ILGA; 2006) that compiles reports of homophobic attacks among adolescents, noted several serious incidents in Portugal.

As evidence suggests that homophobia is a problem in Portugal as in other Western countries, this study further current knowledge on a previously underresearched population. This study is the first of its kind in investigating empirically attitudes toward sexual minorities in a sample of Portuguese adolescents. On the assumption that sexual prejudice in Portuguese adolescents follows the same trend as in other Western countries, it was predicted that adolescents would hold negative attitudes toward transgender individuals, lesbians, and gay men and rigid gender role beliefs, and that these four measures would correlate highly. In addition, it was predicted that young men would hold more negative attitudes toward transgender individuals, lesbians, and gay men, and would adhere more rigidly to gender roles than young women. Regarding differences in sex of target, it was predicted that both young men and young women would be less positive toward gay men than toward lesbians. Finally, it was hypothesized that being acquainted with a transgender person, lesbian, or gay men would positively influence attitudes toward these sexual minorities and also influence positively their gender role beliefs.

\section{METHOD}

\section{Participants}

Participants were recruited from high schools in Lisbon, Portugal. High schools in Portugal consists of the final three of official mandatory school years; students usually enter high school at 15 or 16 years old and finish college at 17 or 18 years old before going to the university. Consent to take part in the study was given by the participants themselves, although, because some of the participants were under the age of 18, the participating schools' head teacher also gave written consent in loco parentis.

Participation was voluntary and 194 completed questionnaires were returned. From these, six questionnaires were excluded because the 
participants were over the age of 19. The final sample consisted of 188 (126 females and 62 males) high school students, all Portuguese citizens. Age ranged from 15 to $19(M=17 ; S D=.964)$. Response rate was high $(78 \%)$.

Participants were asked to describe their ethnic origin and the majority (84\%) were described as White-Caucasian (Portuguese and from other White backgrounds), 12\% were either Black or mixed Black (of African descent), $1 \%$ had other mixed backgrounds, and 1\% any other ethnic background (2\% did not answer). Overall, $7 \%$ of participants were acquainted with a transgender person, and $42 \%$ were acquainted with a lesbian or a gay man; from these, $5 \%$ were acquainted with both a transgender person and a lesbian or a gay man.

\section{Materials}

The questionnaire booklet was designed for this study. On the first page, participants were given a short definition of sexual minorities and of transsexual. Sexual minorities was described as "a concept used to classify people which are different for the majority for reason of being gay, lesbian, or transsexual," whereas "transsexuals are people who identify with one gender that does not correspond to the sex assigned to them at birth, and may seek surgery or hormonal therapy to change their sex." Transsexual was chosen over transgender for simplification reasons considering this study used a sample of adolescents.

Participants were asked about their gender, age, ethnic background, and if they were friends or acquainted with a transgender individual and with a lesbian or a gay man. The questionnaire booklet also included four attitude measures: the Genderism and Transphobia Scale (Hill \& Willoughby, 2005), the Affective Reactions Toward Gay Men Scale (Davies, 2004), the Affective Reactions Toward Lesbian Women Scale (modified from Davies, 2004), and the Gender Roles Beliefs Scale, which was designed especially for the purposes of this study. Each scale will now be considered in more depth.

The Genderism and Transphobia Scale ( consisted of two main components which the authors named "genderism and transphobia" and "gender bashing" with a total of 32 items. Each component revealed high internal consistency, and a coefficient $\alpha$ of .96 for the total score. Discriminative validity and convergent validity analysis revealed high to moderate correlations with homophobia and gender role ideology scales in adult samples (Hill \& Willoughby, 2005).

However, the ethics committee advised that some of the items of the GTS had to be either adjusted or deleted because their strong language was inappropriate for younger adolescents. Items that contained strong or explicit physical and violent aggression statements (e.g., "I have behaved violently toward a man because he was too feminine") were excluded, as well as items that were not explicit, but referred to other past hurtful events 
such as teasing or name calling (e.g., "I have teased a woman because of her masculine appearance or behavior"), and other items needed rewording (e.g., "Men who cross-dress for sexual pleasure disgust me," was changed to "Men who cross-dress disgust me"). From the 32 items of the GTS, a total of 23 were kept. Because some attitudes toward transgender individuals were not measured by these 23 items, another 8 items were adapted from the Male-to-Female transsexuals (MTF) Scale, which measures attitudes and reactions toward disclosure of transgenderism (Davies, 2000) and one other item was written for this study ("It is easier for me to understand someone who undergoes a sex change procedure than someone who cross-dress").

To measure homophobia, the Affective Reactions Toward Gay Men Scale was used (Davies, 2004). For this study, it was developed a scale to measure affective reactions towards lesbians, with the same items for both gay men and lesbians being presented (e.g., "gay men are disgusting," and the correspondent statement for lesbians "lesbian women are disgusting"). The Affective Reactions Toward Lesbians Scale comprised the same items, with wording changed to reflect attitudes toward lesbians, rather than gay men.

A scale to measure gender role beliefs rather than gender role selfconcept was chosen as it is shown to be more related to homophobic attitudes (Whitley, 2001) and expected to be related to transphobic attitudes as well. The scale used was designed for this study based on existing gender role scales in order to be sensitive to two important distinctions; between men and women's roles, and also gender roles in different important contexts for adolescents (namely, relationships, family, and children). Five items were taken from the Gender Roles Belief Scale (Kerr \& Holden, 1996), and reworded for this sample (e.g., "The initiative in courtship should usually come from the man" was changed to "A woman should wait for the man to initiate contact"), eight other items were taken from the Bias in Attitude Survey - a female-male role questionnaire (Jean \& Reynolds, 1980; e.g., "Most women prefer a strong dominating men," or "Little girls should be protected from rough games and the chance of getting hurt"). Finally, five other items were written for this study (e.g., "If a woman goes out to work her husband should share the housework, such as washing dishes, cleaning and cooking").

Items on all scales were measured on a 5-point Likert scale with the anchors of 1 (completely disagree) through 5 (completely agree), with a midpoint (neither agree nor disagree). All measures were translated to Portuguese and back translated to English.

\section{Procedure}

Participants were recruited inside the schools' perimeter during their leisure hours. They were told that this was a study about attitudes toward sexual minorities and they were given a questionnaire booklet to complete in their 
own time. They were also informed that instructions on how to complete and return the questionnaire were given within the booklet, and that they could return the completed questionnaires by leaving them in a secure box in a designated area. Participation was voluntary and unpaid, and anonymity was maintained throughout the study. This study conformed to ethical guidelines as set by the British Psychology Society, and was approved by the University of Central Lancashire's Ethics Committee for Psychology Research.

\section{RESULTS}

Principal Components Analysis

GENDERISM AND TRANSPhOBia SCALE

The final solution revealed six factors with Eigenvalues greater than 1.00. Based on the correlation between the items, it was decided that only one factor should be retained, and seven items were deleted from further analysis due to ambiguity in factor loading. The items that failed to load clearly on to one factor seemed to refer to a cognitive attitude rather than an affective response. Final solution produced one factor comprising 25 items with a coefficient $\alpha$ of .97. The final solution with items and factorials weights is presented on Table 1.

\section{Affective Reactions Toward Gay Men}

As expected, the final solution revealed just one factor with highly correlated items. All items loaded onto this factor, and the internal consistency of this scale was high, with a coefficient $\alpha$ of .93 .

\section{AFFective ReActions TOWARD Lesbians}

Again as expected, the final solution revealed just one factor with highly correlated items. All items loaded onto this factor, and the internal consistency of this scale was high, with a coefficient $\alpha$ of .92 .

\section{Gender Role Beliefs}

The final solution produced four factors with Eigenvalues greater than 1.00. An examination of the factor loadings showed that two factors should be retained, and these were rotated to Varimax criteria. In this two factor solution, three items were deleted due to ambiguity in factor loadings as they seemed to be measuring a different component of gender roles ideology, which could be referred to as benevolent sexism (e.g., "little girls should be protected from rough games and the chance of getting hurt"). Items 
TABLE 1 Items and Factor Loadings of the Negative Attitudes Toward Transgender Individuals Scale

\begin{tabular}{|c|c|c|}
\hline \multirow{2}{*}{$\begin{array}{l}\text { Item } \\
\text { Number }\end{array}$} & Factor Negative Attitudes Toward Transgender Individuals & \multirow{2}{*}{$\begin{array}{l}\text { Factor } \\
\text { Loading }\end{array}$} \\
\hline & Eigenvalue: 15.127 Percentage of explained variance: 60.508 & \\
\hline 13 & A man who dresses as a woman is a pervert & .834 \\
\hline 12 & $\begin{array}{l}\text { I would avoid talking to a woman if I knew she had a surgically created } \\
\text { penis and testicles }\end{array}$ & .823 \\
\hline 19 & Feminine men make me feel uncomfortable & .816 \\
\hline 32 & I feel that males who want to live as women must be sexual perverts & .815 \\
\hline 11 & Women who see themselves as men are abnormal & .807 \\
\hline 10 & I feel that females who want to live as men must be sexual perverts & .796 \\
\hline 15 & Feminine boys and masculine girls should be cured of their problem & .796 \\
\hline 6 & Men who act like women should be ashamed of themselves & .790 \\
\hline 18 & Sex change operations are morally wrong & .790 \\
\hline 3 & Men who cross-dress disgust me & .787 \\
\hline 21 & Masculine women make me feel uncomfortable & .780 \\
\hline 28 & $\begin{array}{l}\text { There must be something seriously psychologically wrong with a } \\
\text { person for wanting sex-change treatment }\end{array}$ & .767 \\
\hline 22 & It is morally wrong for a woman to present herself as a man in public & .764 \\
\hline 16 & $\begin{array}{l}\text { If a man wearing make-up and a dress, who also spoke in a high voice, } \\
\text { approached my child, I would use physical force to stop him }\end{array}$ & .756 \\
\hline 24 & $\begin{array}{l}\text { If I encountered a male who wore high-heeled shoes, stockings, and } \\
\text { make-up, I would consider beating him up }\end{array}$ & .752 \\
\hline 7 & Men who shave their legs are weird & .743 \\
\hline 31 & $\begin{array}{l}\text { I find it very difficult to understand why any male would want to have } \\
\text { a sex-change treatment }\end{array}$ & .737 \\
\hline 26 & $\begin{array}{l}\text { I would find it very difficult to support a person who undergoes } \\
\text { sex-change treatments, even if they asked me to }\end{array}$ & .710 \\
\hline 8 & I can not understand why a woman would act masculine & 708 \\
\hline 20 & People are either men or women & 687 \\
\hline 27 & $\begin{array}{l}\text { I would be happy that transsexuals have treatment, if that is what they } \\
\text { wanted }\end{array}$ & .677 \\
\hline 9 & Children should play with toys appropriate to their own sex & 658 \\
\hline 1 & If I found out that my best friend was changing sex, I would freak out & .627 \\
\hline 25 & $\begin{array}{l}\text { I could stay friends with a person who was thinking of having a } \\
\text { sex-change }\end{array}$ & .595 \\
\hline 14 & $\begin{array}{l}\text { If I found out that my girlfriend / boyfriend had a sex-change, I would } \\
\text { get violent }\end{array}$ & .579 \\
\hline
\end{tabular}

contained in factor 1 were related to women adherence to traditional gender roles, thus, named Attitudes Toward Women's Gender Roles. This factor comprises eight items, with a coefficient $\alpha$ of .86. Items contained in factor 2 related to men's gender roles, thus, Attitudes Toward Men's Gender Roles. This factor comprises seven items, with a coefficient $\alpha$ of .73.

\section{Gender Differences}

Total scores of all attitude measures were calculated. Scores between 25 and 125 were obtained for the Genderism and Transphobia Scale, and scores between 9 and 45 for both Affective Reactions Toward Gay Men and 
Lesbians, with higher scores reflecting extreme negative attitudes. For the Attitudes Toward Women's Gender Roles scores fell between 8 and 40, and between 7 and 35 for the Attitudes toward Men's Gender Roles. High scores on the gender roles dimensions reflected a more conservative view of gender roles. Eighteen percent of the participants agreed that "males who want to live as women must be sexual perverts," and 17\% that "women who see themselves as men are abnormal." It is noteworthy that $60 \%$ of the participants would support a person who underwent a sex change. Eighteen percent of the participants felt that "gay men disgust me," and 19\% that "male homosexuality is a perversion." In contrast only 7 and 11\%, respectively, felt the same about lesbian women.

In order to test the existence of a gender effect on attitudes toward sexual minorities, a series of independent samples $t$ tests were performed. As expected, results showed that young men held more negative attitudes toward transgender individuals, gay men, and lesbian women, and showed more traditional gender role beliefs than young women (Table 2).

To test if there were gender differences in homophobia, a $2 \times 2$ mixed analysis of variance (ANOVA) was performed. It was predicted that both males and females would be more prejudiced against gay men than against lesbian women. The results from this analysis showed a significant interaction effect $\left.F_{(1,186)}=35.505, p<.001\right)$, thus, paired samples $t$ tests were performed. As predicted, results confirmed that both young men $\left(t_{(61)}=\right.$ 6.966, $p<.001)$ and young women $\left(t_{(125)}=3.468, p<.001\right)$ held more negative evaluations of gay men than of lesbian women.

Further, it was predicted that both young men and women who were acquainted with a transgender or homosexual individuals would hold more favorable attitudes toward transgender individuals, gay men, and lesbian women, and hold less traditional gender role beliefs. To test this hypothesis, independent samples $t$ tests were performed across the sample. No significant results were found for young people who were acquainted with a transgender individual, although only 14 young people were acquainted. For young people who were acquainted with a homosexual individual, they were less prejudiced toward gay men $\left(t_{(186)}=4.851, p<.001\right)$, lesbian women $\left(t_{(186)}=4.238, p<.001\right)$, transgender individuals $\left(t_{(186)}=4.404, p<\right.$ $.001)$, and held less traditional perceptions of women's gender roles $\left(t_{(186)}=\right.$ 4.478, $p<.001)$.

\section{Correlations and Predictors of Negative Attitudes}

Associations between the attitude measures were investigated using Pearson's correlations. Results revealed significant positive correlations between all attitudinal measures (between $r=.449$ and $r=.904$; Table 3). 


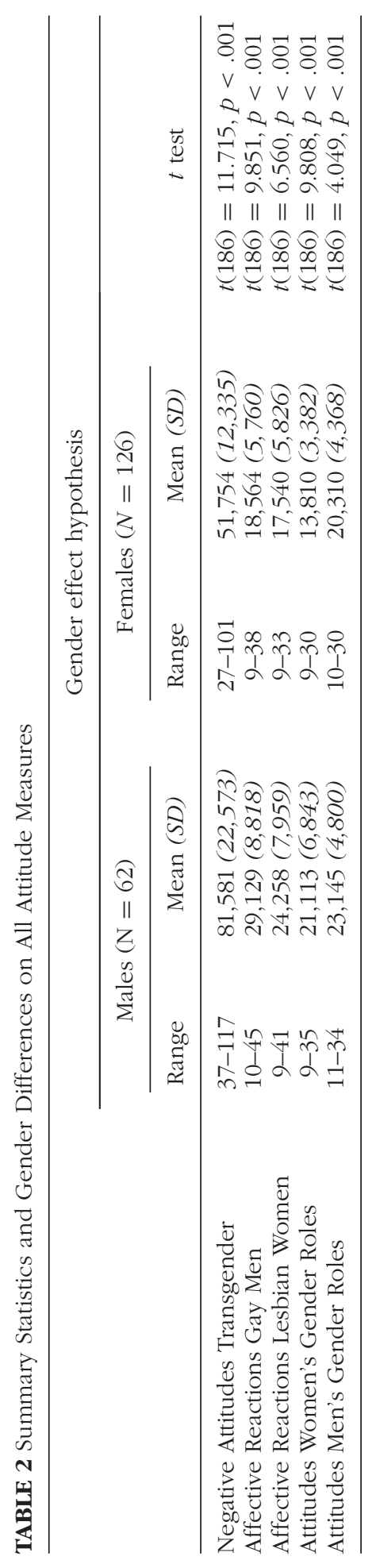


TABLE 3 Pearson's Correlations Between All Attitude Measures

\begin{tabular}{lllll}
\hline & $\begin{array}{c}\text { Negative } \\
\text { Attitudes } \\
\text { Transgender }\end{array}$ & $\begin{array}{c}\text { Affective } \\
\text { Reactions } \\
\text { Gay Men }\end{array}$ & $\begin{array}{c}\text { Affective } \\
\text { Reactions } \\
\text { Lesbian } \\
\text { Women }\end{array}$ & $\begin{array}{c}\text { Attitudes } \\
\text { Women's } \\
\text { Gender } \\
\text { Roles }\end{array}$ \\
\hline $\begin{array}{l}\text { Negative Attitudes Transgender } \\
\text { Affective Reactions Gay Men }\end{array}$ & & & \\
Affective Reactions Lesbian Women & $.904^{*}$ & $.750^{*}$ & $.846^{*}$ & \\
Attitudes Women's Gender Roles & $.762^{*}$ & $.735^{*}$ & $.669^{*}$ & $.492^{*}$ \\
Attitudes Men's Gender Roles & $.549^{*}$ & $.539^{*}$ & $.449^{*}$ \\
\hline
\end{tabular}

${ }^{*} \mathrm{p}<.001$.

In addition, three hierarchical multiple regressions were performed in order to explore 1) which variables were more predictive of negative attitudes toward transgender individuals (GTS); 2) which variables were more predictive of Affective Reactions Toward Gay Men; and 3) which variables were more predictive of Affective Reactions Toward Lesbian Women. Attitudes Toward Women's Gender Roles and Attitudes Toward Men's Gender Roles were entered first in the equation as mediators of negative attitudes toward sexual minorities, followed by gender in the second block, and acquaintance with a transgender person and with a lesbian or a gay man in the third block. Finally, Affective Reaction Toward Gay Men and Affective Reactions Toward Lesbian Women were introduced in the last block. Although the attitudes measures were expected to be correlated since they are measuring similar attitudes, the issue of multicollinearity may arise. This was tested for the three models and all tolerance values were above the minimum tolerance values.

\section{GENDERISM AND TRANSPHOBIA}

In step one, both Attitudes Toward Women's Gender Roles and Attitudes Toward Men's Roles emerged as highly significant predictors, and, in step two, gender also emerged as a highly significant predictor. Acquaintance with a transgender person, a gay man, or a lesbian woman did not have any significant impact on the overall model. Finally, from the homophobia measures, only Affective Reactions Toward Gay Men emerged as a significant predictor (Table 4a).

\section{AfFective Reactions Toward Gay Men}

Only Attitudes Toward Women's Gender Roles, Attitudes Toward Men's Gender Roles, and Gender emerged as highly significant predictors (Table 4b). 
TABLE 4A Multiple Regression for Negative Attitudes Toward Transgender Individuals

Block 1

Attitudes Women's Gender Roles

$\begin{array}{ccc}\text { Beta } & t & \text { Sig } t \\ .646 & 12.993 & <.001 \\ .259 & 5.212 & <.001\end{array}$

Attitudes Men's Gender Roles

Block 2

Gender

$\begin{array}{cccl}\text { Beta } & t & \text { Sig } t & \text { Sig change } \\ .305 & 6.082 & <.001 & \\ & & & F_{(1,184)}=36.990, p<.001\end{array}$

Block 3

Acquaintance with transgender

Acquaintance with gay/lesbian

$\begin{array}{lccl}\text { Beta } & t & \text { Sig } t & \text { Sig change } \\ .020 & .466 & >.05 & \\ .032 & .724 & >.05 & \\ & & & F_{(2,182)}=.466, p .<05\end{array}$

Block 4

Affective Reactions Gay Men

$\begin{array}{cccl}\text { Beta } & t & \text { Sig } t & \text { Sig change } \\ .702 & 10.945 & <.001 & \\ .052 & .937 & >.05 & F_{(2,180)}=100.230, p<.001\end{array}$

TABLE 4B Multiple Regression for Affective Reactions Toward Gay Men

Block 1

Attitudes Women's Gender Roles

$\begin{array}{ccc}\text { Beta } & t & \text { Sig } t \\ .617 & 11.794 & <.001 \\ .262 & 5.007 & <.001\end{array}$

Attitudes Men's Gender Roles

Block 2

Gender

$\begin{array}{ccc}\text { Beta } & t & \text { Sig } \\ 229 & 4.133 & <001\end{array}$

Sig change

$F_{(1,184)}=17.080, p<.001$

Block 3

Acquaintance with transgender

Acquaintance with gay/lesbian

$\begin{array}{lccl}\text { Beta } & t & \text { Sig } t & \text { Sig change } \\ .002 & .034 & >.05 & \\ .088 & 1.797 & >.05 & \\ & & & F_{(2,182)}=1.709, p>.05\end{array}$

\section{AfFective ReACTIONS TOWARD LESBIAN WOMEN}

In predicting Affective Reactions Toward Lesbian Women, only Gender Role Attitudes emerged as significant predictors (Table 4c).

\section{DISCUSSION}

Principal components analysis of the GTS individuals revealed the existence of just one component including both genderism and transphobia and gender-bashing factors from the original GTS Scale. After excluding the 
TABLE 4C Multiple Regression for Affective Reactions Toward Gay Men

\begin{tabular}{lcccc}
\hline Block 1 & & & & \\
& Beta & $t$ & Sig $t$ & \\
Attitudes women's gender roles & .561 & 9.588 & $<.001$ & \\
Attitudes men's gender roles & .240 & 4.109 & $<.001$ & \\
Block 2 & & & & \\
& Beta & $t$ & Sig $t$ & Sig change \\
Gender & .057 & .880 & .380 & \\
& & & & $\mathrm{~F}_{(1,184)}=.775, \mathrm{p}>.05$ \\
Block 3 & & & & \\
& Beta & $t$ & Sig $t$ & Sig change \\
Acquaintance with transgender & .082 & 1.521 & .130 & \\
Acquaintance with gay/lesbian & .110 & 1.934 & .055 & $F_{(2,182)}=2.505, p>.05$ \\
& & & &
\end{tabular}

cognitive items, the scale was more of an affective measure of prejudice toward transgender individuals than what the original validation of this scale proposed.

Both Affective Reactions Toward Gay Men and Affective Reactions Toward Lesbian Women scales revealed just one component with highly correlated items. This finding extends previous research on affective reactions toward gay men (Davies, 2004), proving to be a reliable scale to measure affective reactions toward lesbians.

Results showed that Affective Reactions Toward Gay Men was a strong predictor of genderism and transphobia, which confirms and extends previous research (Davies, 2000; Leitenberg \& Slavin, 1983; Hill \& Willoughby, 2005). This finding confirms that transphobia and homophobia are important dimensions of a whole negative attitude toward people who show some level of gender nonconformism.

It is not surprising that attitudes toward gay men and toward lesbians were highly correlated, since they both measure attitudes toward homosexual individuals. However, attitudes toward gay men were more closely linked with attitudes toward transgender individuals, reinforcing the importance of sex of target in predicting prejudicial attitudes toward sexual minorities. In this sense, it may also indicate that young people think of transgender individuals as males posing as women, as it is reinforced by society in general.

These results also indicated a general negative reaction toward sexual minorities largely explained by gender. Not only young men judged more negatively transgender individuals, gay men, and lesbian women, but also they were more negative against gay men than against lesbians. Gender socialization of young men is much more rigid than of young women, and a large part of this is the endorsement of homophobic attitudes (Archer, 1984; Badinter, 1997; Eagly et al., 2004). The endorsement of traditional gender 
roles is used as a framework to draw distinctions between clearly masculine young men and less masculine young men, thus, regarded as being more feminine and more gay-like (Korobov, 2004; Plummer, 2001).

As suggested by the present results, genderism (Hill, 2002; Hill \& Willoughby, 2005) explains these attitudes better. It assumes that the institutional norm moves beyond sexism, to a standpoint in which being heterosexual is the logic continuity of adopting and behaving according to one's gender. The consequences for trespassing gender barriers are punishable for both genders, although men are more rigid in their adherence to the prescribed gender roles, and adolescents being labeled as gay or lesbian by their peers is more a testimonial of their gender defiance than their actual sexual and romantic attractions (Nayak \& Kehily, 1996). Prejudice against lesbians, in contrast, is less pervasive because they are stereotypically regarded as having less cross-gender traits and behaviors, and are given more latitude in their gender expressions (Fagot, 1977; Thompson et al., 1985).

In predicting attitudes toward transgender individuals, lesbians, and gay men, women's gender roles beliefs had a larger weight than did men's gender roles. The explanation for this finding might rely on the fact that most items that expressed women's gender roles related to women's defying traditional gender roles, while items that expressed men's gender roles referred to men conformism to traditional gender roles. However, both gender role beliefs components seemed to have a mediating effect of other variables on attitudes toward transgender individuals. In the case of attitudes toward lesbians, it was the only variable that significantly explained that prejudicial attitude. This finding is again reinforcing the gender bias between gay men and lesbians.

In line with research on the role of familiarity with minority groups on attitude change (Anderssen, 2002; Herek \& Glunt, 1993), being acquainted with a lesbian or with a gay man lead to a more favorable attitude toward transgender individuals, lesbians, and gay men, but there was no difference in attitudes if they were acquainted with a transgender individual. However, the fact that there was no significant attitude change is more likely due to the very small number of adolescents acquainted with a transgender person than to the inexistence of a real effect. It would be interesting to further investigate this issue with a larger sample of people with transgender acquaintances.

Results from this study suggested that sexual prejudice is prevalent to some degree in this sample of Portuguese adolescents, particularly in the male participants. As research has previously shown, men in general are more negative toward those who are perceived as transgressing gender scripts, and they are harsher toward gay men than toward lesbians (Fineran, 2002; Herek, 2000). Because there is so little work in this area outside of the United States and selective European countries, this study marks the beginning of equivalent work in Portugal. The link between negative attitudes shown by adolescents in Portugal and how this relates to the continuation of 
homophobic harassment and bullying is one suggestion for future research. The findings of the present study indicate that the role that affective attitudes and gender expectations play as a base for prejudice toward sexual minorities in Portugal, as in the United States and other parts of Europe. As in other cultures, it is important for education about homophobic bullying and abuse to continue and extend in Portugal. This issue should be addressed further among those working in educational establishments in Portugal, as in the United State and Europe generally.

A further point to be made in relation to education, while young people are still developing their own sexual and gender identity, it is positive to be familiar with people with different romantic and sexual attractions. Getting familiar with people with different sexual and romantic attractions, either directly or indirectly, can help to prevent homophobic-based bullying and harassment in schools. Open communication about sexuality, sexual orientation, and gender nonconformism helps to create a safer environment for sexual minority youth (Hilton, 2001; Lance, 2002b), as well as to assist youth in general in asserting their identity in a constructive way, without compromising their sense of identity (Konik \& Stewart, 2004). This work needs to be furthered in Portugal as it is still in its early stages.

\section{CONCLUSION}

This was one of the first studies aimed at exploring attitudes toward transgender individuals and its correlates, and it was one of the few attitudes' studies addressing prejudice toward sexual minorities with a pre-adult sample. As stated before, there is a lack of studies on the prevalence of negative attitudes toward gender nonconformists, or sexual minorities, in Portugal. Nevertheless, it was shown that the significance of sexual prejudice in Portuguese adolescents is similar to any other Western country adolescents' development. These negative attitudes foster an unsafe and abusive atmosphere for people who are perceived as having cross-gender behaviors, and are closely linked with homophobic bullying and harassment in schools.

The lack of studies conducted in Portugal makes it difficult to contextualize the present results within a general genderist atmosphere as suggested, although findings are consistent with those of United States and other European populations, and further investigation is needed to explore the connection between these attitudes and bullying, as well as the prevalence of homophobic-based in school bullying. However, the results presented here help to cast some light on the nature of homophobic and transphobic attitudes as part of the construction of an adolescent gendered personality. Investigating the prevalence and correlates of prejudicial attitudes at young ages may help to develop more accurate sex education programs in schools, 
so to prevent prejudice and bullying, and to impede the continuance of victimization of lesbian, gays, and other gender nonconformists throughout their adolescence and adulthood.

\section{REFERENCES}

Adams, N., Cox, T., \& Dunstan L. (2004). I am the hate that dare not speak its name: Dealing with homophobia in secondary schools. Educational Psychology in Practice, 20, 259-269.

Adams, G. R., Ryan, J. H., Hoffman, J. J., Dobson, W. R., \& Nielsen, E. C. (1985). Ego identity status, conformity behavior, and personality in late adolescence. Journal of Personality and Social Psychology, 47, 1091-1104.

Anderssen, N. (2002). Does contact with lesbians and gays lead to friendlier attitudes? A two year longitudinal study. Journal of Community \& Applied Social Psychology, 12, 124-136.

Allport, G. W. (2000). The nature of prejudice. In C. Stangor (Ed.), Stereotypes and Prejudice: essential readings (pp. 20-48). New York, NY: Psychology Press.

Archer, J. (1984). Gender roles as developmental pathways. British Journal of Social Psychology, 23, 245-256.

Badinter, E. (1997). XY: On masculine identity. New York, NY: Columbia University Press.

Bullough, V. L. (2006). Transgenderism and the concept of gender. Retrieved from http://symposion.com/ijt/gilbert/bullough.htm.

D'Augelli, A. R. (1989). Lesbian's and gay men's experiences of discrimination and harassment in a university community. American Journal of Community Psychology, 17, 317-321.

Davies, M. (2000). When a friend has a sex-change: social support, homophobia and gender. Paper presented at the British Psychological Society, Psychology of Women Conference, July, University of Dundee, UK.

Davies, M. (2004). Correlates of negative attitudes toward gay men: sexism, male role norms, and male sexuality. Journal of Sex Research, 41, 259-266.

Eagly, A. H., Wood, W., \& Johannesen-Schmidt, M. C. (2004). Social role theory of sex differences and similarities: implications for the partner preferences of women and men. In A. H. Eagly, A. E. Beall, \& R. J. Sternberg (Eds.). The psychology of gender (pp. 269-295). New York, NY: Guilford Press.

Elze, D. E. (2003) Gay, lesbian and bisexual youths' perceptions of their high school environments and comfort in school. Children and Schools, 25, 225-239.

Erikson, E. H. (1968). Identity: youth and crisis. Oxford, UK: Norton \& Co.

Fagot, B. (1977). Consequences of moderate cross-gender behaviour in preschool children. Child Development, 48, 902-907.

Fineran, S. (2002). Sexual harassment between same-sex peers: intersection of mental health, homophobia, and sexual violence in schools. Social Work, 47, 65-74.

Freire, I. P. (2001). Percursos disciplinares e contextos escolares-dois estudos de caso [Disciplinary paths and school contexts-Two case studies]. Tese de Doutoramento, Lisboa: Faculdade de Psicologia e de Ciências da Educação da Universidade de Lisboa. 
Graber, J. A., \& Archibald, A. B. (2001). Psychosocial change at puberty and beyond: Understanding adolescent sexuality and sexual orientation. In A. R. D'Augelli \& C. J. Patterson (Eds.). Research on lesbian, gay, and bisexual youths: Implications for developmental intervention (pp. 3-26). New York, NY: Oxford University Press.

Herek, G. M. (1988) Heterosexuals' attitudes toward lesbian and gays men: correlates and gender differences. Journal of Sex Research, 25, 451-477.

Herek, G. M. (1989). Hate crimes against lesbians and gay men-Issues for research and policy. American Psychologist, 49, 948-955.

Herek, G. M. (2000) Sexual prejudice and gender: do homosexuals' attitudes toward lesbian and gay men differ? Journal of Social Issues, 56, 251-266.

Herek, G. M., \& Glunt, E. K. (1993). Interpersonal contact and heterosexuals' attitudes toward gay men: results from a national survey. Journal of Sex Research, 30, 239-244.

Hill, D. B. (2002). Genderism, transphobia, and gender bashing: a framework for interpreting anti-transgender violence. In B. Wallace \& Carter (Eds.), Understanding and dealing with violence: A multicultural approach (pp. 113-136). Thousand Oaks, CA: Sage.

Hill, D. B., \& Willoughby, B. L. B. (2005). The development and validation of the genderism and transphobia scale. Sex Roles, 53, 531-544.

Hilton, G. L. (2001). Sex education-The issues when working with boys. Sex Education, 1, 31-41.

International Lesbian and Gay Association. (2006, January). Situação Portuguesa: enquadramento jurídico geral [Portuguese Situation: General legal framework]. Retrieved from http://ilga-ortugal.oninet.pt/glbt/situacao_portuguesa.htm

Jean, P. J., \& Reynolds, C. R. (1980). Development of the bias in attitudes survey: a sex-role questionnaire. Journal of Psychology, 104, 269-277.

Kerr, P. S., \& Holden, R. R. (1996). Development of the gender role beliefs scale (GRBS). Journal of Social Behavior \& Personality, 11, 3-16.

Kite, M. E., \& Whitley, B. E. (1996). Sex differences in attitudes toward homosexual persons, behaviors, and civil rights: a meta analysis. Personality and Social Psychology Bulletin, 22, 336-353.

Kite, M. A., \& Whitley, B. E. (1998). Do heterosexual women and men differ in their attitudes toward homosexuality? A conceptual and methodological analysis. In G. Herek (Ed.). Stigma and sexual orientation: Understanding prejudice against lesbians, gay men, and bisexuals (pp. 39-61). Thousand Oaks, CA: Sage.

Koborov, N. (2004) Inoculating against prejudice: a discursive approach to homophobia and sexism in adolescent male talk. Psychology of Men $\varepsilon$ Masculinity, 5, 178-189.

Konik, J., \& Stewart, A. (2004). Sexual identity development in the context of compulsory heterosexuality. Journal of Personality, 72, 815-844.

Lance, L. M. (2002a). Acceptance of diversity in human sexuality: will the strategy reducing homophobia also reduce discomfort of cross-dressing? College Students Journal, 36, 598-602.

Lance, L. M. (2002b) Heterosexism and homophobia among college students. College Students Journal, 36, 410-414.

Leitenberg, H., \& Slavin, L. (1983). Comparison of attitudes toward transsexuality and homosexuality. Archives of Sexual Behavior, 12, 337-346. 
Meyer, I. H. (2003). Prejudice, social stress, and mental health in lesbian, gay and bisexual populations: conceptual issues and research evidence. Psychological Bulletin, 129, 674-697.

Nayak, A., \& Kehily, M. J. (1996). Playing it straight: masculinities, homophobias and schooling. Journal of Gender Studies, 5, 211-230.

OSCE, Office for Democratic Institutions and Human Rights, (2007). Hate-crimes in the OSCE region: Incidents and responses. Annual Report for 2006. Retrieved from http://www.osce.org/publications/odihr/2007/09/26296_931_en.pdf

Pereira, B. O., \& Mendonça, D. (1995). O bullying na escola. Análise das práticas agressivas por ano de escolaridade [Bullying in schools. Analysis of agressive behavior by school year]. In 1 Encontro de Educação e Cultura do Concelho de Oeiras, Oeiras: Câmara Municipal de Oeiras, 39-57.

Pereira, B. O.; Almeida, A. T.; Valente, L., \& Mendonça, D. (1996). O bullying nas escolas portuguesas. Análise das variáveis fundamentais para a identificação do problema [Bullying in Portuguese schools. Analysis of the main variables to identify the problem]. In L. Almeida, J. Silvério \& S. Araújo (Eds.), Actas do II Congresso Galaico-Português de Psicopedagogia (pp. 71-81). Braga, Portugal: Universidade do Minho.

Plummer, D. C. (2001). The quest for modern manhood: masculine stereotypes, peer culture and the social significance of homophobia. Journal of adolescence, 24, $15-23$.

Rayburn, N. R., \& Davidson, G. C. (2002). Articulated thoughts about antigay hate crimes. Cognitive Therapy and Research, 26, 431-447.

Rede ex aequo (2006). Observatório de Educação-Relatório sobre homofobia e transfobia [Education Observatory-Homophobia and transphobia annual report]. Retrieved from http://www.rea.pt/arquivo/observatorio/OE2006.pdf

Rede ex aequo. (2008). Observatório de Educação-Relatório sobre homofobia e transfobia [Education Observatory-Homophobia and transphobia annual report]. Retrieved from http://www.rea.pt/arquivo/observatorio/OE2008.pdf

Rich, A. (1983). Compulsory heterosexuality and lesbian existence. In A. Snitow, C. Stansell, \& S. Thompson (Eds.), Power of desire: thE politics of sexuality (pp. 177-205). New York, NY: Monthly Review Press.

Sharpe, S. (2002). It's just really hard to come to terms with: Young people's views on homosexuality. Sex Education, 2, 263-277.

Simon, W., \& Gagnon, J. H. (1986). Sexual scripts: permanence and change. Archives of Sexual Behavior, 15, 97-120.

Thompson, E. H., Grisanti, C., \& Pleck, J. H. (1985). Attitudes toward the male role and their correlates. Sex Roles, 13, 413-427.

Veiga Simão, A. M., Freire, I., \& Sousa Ferreira, A. (2004). Maus-tratos entre pares na escola-um estudo contextualizado [Harassment between peers in school]. Actas do Congresso Ibero-Americano sobre Violência nas Escolas, Brasília, Paper presented at Congresso Iberoamericano sobre Violência nas Vscolas, Brasil, April 28.

Whitley, B. E. (2001). Gender-role variables and attitudes toward homosexuality. Sex Roles, 45, 691-721

Willis, D. G. (2004). Hate crimes against gay males: an overview. Issues in Mental Health Nursing, 25, 115-132. 